\title{
The Implementation of Blended Learning and Peer Tutor Strategies in Pandemic Era: A Systematic Review
}

\author{
Nurfina Aznam ${ }^{1, *}$ Riki Perdana ${ }^{2,}$ Jumadi Jumadi ${ }^{3,}$ Heru Nurcahyo ${ }^{4,}$ Yusman \\ Wiyatmo $^{5}$
}

\author{
${ }^{1}$ Department of Chemistry Education, Faculty of Mathematics and Natural Sciences, Universitas Negeri \\ Yogyakarta, Indonesia \\ ${ }^{2}$ Doctoral of Science Education, Faculty of Mathematics and Natural Sciences, Universitas Negeri Yogyakarta, \\ Indonesia \\ ${ }^{3}$ Department of Physics Education, Faculty of Mathematics and Natural Sciences, Universitas Negeri \\ Yogyakarta, Indonesia \\ ${ }^{4}$ Department of Biology Education, Faculty of Mathematics and Natural Sciences, Universitas Negeri \\ Yogyakarta, Indonesia \\ ${ }^{5}$ Department of Science Education, Faculty of Mathematics and Natural Sciences, Universitas Negeri \\ Yogyakarta, Indonesia \\ *Corresponding author. Email: nurfina_aznam@uny.acid
}

\begin{abstract}
The purpose of this study is to analyze the implementation of Blended Learning and Peer Tutor Strategies in the Pandemic Era from Higher Education in Indonesia. A systematic literature review was conducted from July 2020 until November 2020. This study includes a literature review of relevant research on the implementation of Blended Learning and Peer tutor strategy in the Pandemic Era from December 2019 until November 2020. The object of research was the blended learning and peer tutor strategy in Pandemic Era. In the beginning, there were 504 articles about Blended Learning. After the screening process based on inclusion and exclusion criteria, there were 10 selected papers in this study. The result showed that it had been found that blended learning and peer tutor strategy gave a positive impact on students outcome. The study showed that Blended Learning and peer tutor had a potential effect to increase student achievement in learning. Therefore, it need to develop a special learning model to keep student achievement in college. The implication of this study was that the integrated Blended learning model with peer tutors can be a solution for organizing learning at the postgraduate level during a pandemic. Through this model there were many positive influences on student learning outcomes. This study also presented a method that was often used on the topic of blended learning and peer tutors.
\end{abstract}

Keywords: Blended learning, Peer tutor, Pandemic era, Systematic review, Achievement of student

\section{INTRODUCTION}

The Covid-19 pandemic has had many influences on human life. In the field of education, until now many countries in the world have temporarily closed all schools in their countries. The lockdown policy makes learning activities both at school and the college moved at home [1]. Lockdown makes online or online learning more vigorous because activities outside the home are prohibited except for very important matters. During the lockdown, many students at the primary, secondary and high school levels use technology devices to support learning.

The lockdown policy caused several problems. Some of these problems include (1) lack of mastery of technology, (2) cost of internet access, (3) time of parents in accompanying children to study, (4) lack of communication and socialization between students, teachers, and parents, and (5) hours unlimited work for teachers. [2]. In addition, this 
lockdown policy also poses a serious threat to the country's economic growth, especially since the case of this pandemic is still unknown when it will end due to the high cost of the lockdown [3].

The term new normal refers to a new normal order in a life that is different from the normal conditions before the pandemic [4]. In this new normal period, several countries in the world began to call for living "at peace" with Covid-19 by implementing certain protocols or regulations. This certainly greatly affects and changes the lifestyle of the people in various fields. All aspects of people's lives will be regulated by certain protocols until a vaccine for this virus is found. In education, appropriate learning models are needed at all levels. One of the appropriate models to do in the new normal era is blended learning.

Blended learning is carried out by mixing the learning process with face-to-face and online learning [5]. This will be very suitable for the new normal era, in which social activities begin to be reduced without reducing the essence of learning. In addition, blended learning has many positive effects on learning such as improving learning outcomes [6], achievement and motivation [7], scientific attitudes, and independent learning skills [8]. However, specifically at the postgraduate level, new strategies are still needed besides blended learning to suit the characteristics of learning in higher education.

Blended learning is a series of content blocks that are sequenced to create a learning experience and can be managed and tracked by start and end. Blended learning is professional learning, which matches the learning objectives with the most appropriate delivery media and learning environment. This aims to ensure that participants learn through facilitatorled content delivery while using multiple elements of control. Apart from this formal learning experience, blended learning also includes experiences that occur outside the formal curriculum. Designers who learn must remember that learning is timeless, occurs around students [9].

Through a combination of face-to-face and online activities, blended learning has great potential to regulate different teaching in higher education [10]. Blended-learning is a flexible approach in which the program includes a combination of different places and times that can be used to study. While learning is described as an act of understanding or understanding something, etymologically it can be concluded as a combination of the practice of instructional learning activities [11]. There are some parameters of blended learning as in the following Table 1 [12].
Blended learning in this study is defined as the adoption of web-based educational technology (i.e., learning management systems) for online learning, which is used in combination with face-to-face, placed instruction from teaching practitioners [13].

One of the goals of attending a university is to acquire more knowledge and expand assistance in creating a knowledge society [14]. Postgraduate school education is expected to develop students to acquire the ability to play a leading role in a multidisciplinary and international society as well as higher-level competencies based on their specialization [15]. Designing graduate learning should reflect the nature of graduate education, including constructing a suitable curriculum, creating classic original study, realizing cutting-edge, individual, and innovative goals [16]. For graduate students, practical teaching deepens students' understanding of theoretical knowledge, generates new understanding and thinking, solves problems, and explores student initiatives [17]. It includes good writing, quantitative, writing, comprehension, and analytical skills. The graduate school process requires students to have good analytical, comprehension, quantitative, and writing skills [18]. A course on teaching and learning to train graduate students in a discipline-specific context and in student-centred pedagogy had been developed [19].

Learning in higher education requires students to study independently of learning to teaching and teaching to learning [20]. In new normal, this activity can still be carried out. Lecturers can apply the peer tutor strategy for students in blended learning with technological devices. In addition, the peer tutor strategy also has many benefits such as a positive attitude and level of learning satisfaction [21], success in learning [22], or learning outcomes [23], and student participation [24]. Therefore, integrated blended learning with peer tutors is the most appropriate alternative for implementing new normal era learning at the college level

Teaching for learning and learning to teaching focuses on the quality of teaching in higher education. This emphasizes the role that peer review can play, where teaching supports the enhancement of these activities in teaching practice and learning outcomes. This agenda is a further development of higher education through the activities of global institutions, higher education institutions, scientific disciplines, and individual teachers [25].

Peer tutors often involve one-on-one sessions on formal tutoring sessions in a university setting [26]. Not all peer tutors are "experts". They are sometimes 
Table 1. Parameter of blended learning

\begin{tabular}{|l|l|l|}
\hline No & \multicolumn{1}{|c|}{ Parameter } & \multicolumn{1}{c|}{ Descrtiptions } \\
\hline 1 & Learning objective & To increase a positive attitude in learning \\
\hline 2 & Content & Active learning, accepting, responding and assessing \\
\hline 3 & Pedagogic Approach & Dialog \\
\hline 4 & Learning activity & $\begin{array}{l}\text { Socratic questions, self-reflection, online peer discussions, face to face } \\
\text { class discussions facilitated by the teacher }\end{array}$ \\
\hline 5 & Resource and technology & Online forums, websites \\
\hline 6 & Blended Learning Model & $\begin{array}{l}\text { Individual reflections, personal experiences, messages, socratic } \\
\text { questions }\end{array}$ \\
\hline
\end{tabular}

randomly assigned, classmates of the same age or those of lesser achievers of the same age. The term "peer tutor" often replaces tutors of the same age [27]. In peer tutor, students generally identify more easily than with older (teachers/lecturers), and this helps create an environment where students are more comfortable to ask questions and work through challenging problems in a free-form classroom environment [28].

Peer tutors can be experts, classmates of the same age, accomplished or not. Therefore, there are various teaching approaches, developed by educators or researchers based on the concept of peer interaction that can improve student performance in various academic fields or in behaviour management. Classical peer tutors, reciprocal peer tutors, peerassisted learning strategies, and cross-age tutoring are examples of peer tutoring strategies [29].

The open learning environment established in the Peer tutor environment invites students to take responsibility for their own and their peers' learning, including metacognitive regulating the collaborative learning process [30]. In this study, peer tutor strategy refers to peer tutoring conducted by postgraduate students with relatively the same age and ability classifications. Peer tutors are conducted online using an existing website. Based on the previous explanation, it is necessary to analyze appropriate and effective learning held by all universities. Therefore, the researcher tries to conduct a literature study to describe the effectiveness of blended learning and peer tutor at Indonesia higher education in Pandemic Era learning toward students thinking skill, cognitive skill and softskill.

\section{METHOD}

This study presents a systematic review of research examining the students' outcome when learning with Blended learning and Peer Tutor strategy in the Pandemic Era. This systematic review included the learning objective, the selected journal, the exclusion and inclusion criteria, search strategy, and databases. The criteria for the analysis of the results followed the recommendations of the PRISMA (Preferred Reporting Items for Systematic Reviews and Meta-Analyses) statement [31]. The declaration from PRISMA is the global and approved revised version of the declaration from QUORUM (Quality of Meta-analysis reporting) [32]. The review question was: "How student Outcome can be increased by using blended learning and peer tutor strategy in Pandemic Era?'

The analysis of the paper conducted by two researchers. Data were collected and organized in a table that contains the year, author, method, and students' outcome. A literature search was conducted using the following online databases Science Direct, Google scholar, and Scopus. It is covered the period from December 2019 to November 2020 and limited in English. At the beginning of Blended learning, we got 504 articles, after screening based on the inclusion and exclusion criteria, there were 10 selected papers. While there where 385 article about peer tutor before screening process. After we finished the screening process based on the criteria inclusion and extraction, only one selected paper to analyse. The criteria of inclusion and extraction are shown in Table 2. 
Table 2. Criteria inclusion and exclusion selected paper

\begin{tabular}{|l|l|l|}
\hline \multicolumn{1}{|c|}{ Criteria } & \multicolumn{1}{c|}{ Inclusion } & \multicolumn{1}{c|}{ Exclusion } \\
\hline Type & Indexed journal and Conference & Non-Indexed Journal \\
\hline Tittle & Mention "Blended Learning or peer tutor" & No Mentioned \\
\hline Language & English & Non-English \\
\hline Timeline & Between December 2019 - November 2020 & Less than December 2019 \\
\hline Country & Indonesia & Non Indonesia \\
\hline Topic & $\begin{array}{l}\text { The impact of Blended learning or peer tutor } \\
\text { toward students achievement }\end{array}$ & Other topics \\
\hline Sample/Participant & Student from College/University & Non College/University \\
\hline
\end{tabular}

\section{RESULTS AND DISCUSSION}

To identify some articles describing blended learning and peer tutor strategy, a systematic review was conducted. The study focused on student outcomes such as cognitive skill, thinking skill, and soft skill in blended learning and peer tutor strategy on Pandemic Era.

Table 3. Analysis of selected paper

\begin{tabular}{|c|c|c|c|}
\hline Paper & Sample & Method & Student Outcome \\
\hline $\begin{array}{l}\text { Paper } 1 \\
\text { [33] }\end{array}$ & $\begin{array}{l}\text { College student from } \\
\text { biologi Education/fifth } \\
\text { semester (76) }\end{array}$ & Quasi experiment & $\begin{array}{l}\text { Blended learning are potential to increase the } \\
\text { creative thinking skill. } \\
\text { Blended learning are more effective than } \\
\text { conventional model in increasing creative } \\
\text { thinking skill }\end{array}$ \\
\hline $\begin{array}{l}\text { Paper } 2 \\
{[34]}\end{array}$ & $\begin{array}{l}\text { Student from a } \\
\text { university Elementary } \\
\text { School Teacher } \\
\text { Education (30) }\end{array}$ & Quasi experiment & $\begin{array}{l}\text { Use of the moodle blended-learning learning } \\
\text { model in Elementary School Teacher Education } \\
\text { students during the COVID-19 pandemic era is } \\
\text { effective and can be used as a network-based } \\
\text { learning solution or online }\end{array}$ \\
\hline $\begin{array}{l}\text { Paper } 3 \\
{[35]}\end{array}$ & $\begin{array}{l}\text { Students from the sixth } \\
\text { semester of } \\
\text { mathematics education } \\
\text { study program (4) }\end{array}$ & $\begin{array}{l}\text { Descriptive } \\
\text { qualitative research }\end{array}$ & $\begin{array}{l}\text { The results of the Blended learning study } \\
\text { concluded that the average level of } \\
\text { mathematical disposition of students } \\
\text { was classified as moderate. }\end{array}$ \\
\hline $\begin{array}{l}\text { Paper } 4 \\
{[36]}\end{array}$ & $\begin{array}{l}\text { Students at fifth and } \\
\text { sixth semester from a } \\
\text { University Riau (no } \\
\text { mentioned) }\end{array}$ & $\begin{array}{l}\text { Survey method } \\
\text { using questionnaire }\end{array}$ & $\begin{array}{l}\text { Blended learning has strongly impacted } \\
\text { student's academic productivity performance. }\end{array}$ \\
\hline $\begin{array}{l}\text { Paper } 5 \\
{[37]}\end{array}$ & $\begin{array}{l}\text { Students in STKIP } \\
\text { Bandar Lampung (no } \\
\text { mentioned) }\end{array}$ & $\begin{array}{l}\text { Development } \\
\text { research using } \\
\text { ADDIE method }\end{array}$ & $\begin{array}{l}\text { Students had positive responses to the Blended } \\
\text { learning developed, and Blended learning was } \\
\text { very useful in improving the quality of lectures }\end{array}$ \\
\hline $\begin{array}{l}\text { Paper } 6 \\
{[38]}\end{array}$ & $\begin{array}{l}\text { Students from the } \\
\text { Department of } \\
\text { Electronic Engineering } \\
\text { Education (92) }\end{array}$ & Quasi experiment & $\begin{array}{l}\text { the implementation of blended learning is } \\
\text { effective in increasing the students' critical } \\
\text { thinking and communication skills }\end{array}$ \\
\hline
\end{tabular}




\begin{tabular}{|c|c|c|c|}
\hline Paper & Sample & Method & Student Outcome \\
\hline $\begin{array}{l}\text { Paper } 7 \\
\text { [39] }\end{array}$ & $\begin{array}{l}\text { Students from the } \\
\text { second semester } \\
\text { majoring in informatics } \\
\text { engineering at STMIK } \\
\text { STIKOM Indonesia } \\
\text { campus (no } \\
\text { mentioned) }\end{array}$ & Quasi experiment & $\begin{array}{l}\text { student mathematics learning outcomes taught } \\
\text { with blended learning were better than } \\
\text { conventional mathematics learning outcomes. }\end{array}$ \\
\hline $\begin{array}{l}\text { Paper } 8 \\
{[40]}\end{array}$ & $\begin{array}{l}\text { Second-year students } \\
\text { from the Department } \\
\text { of Electrical } \\
\text { Engineering, State } \\
\text { University of Malang } \\
(54)\end{array}$ & Quasi experiment & $\begin{array}{l}\text { The results were reported that students who } \\
\text { used blended learning obtained higher scores }\end{array}$ \\
\hline $\begin{array}{l}\text { Paper } 9 \\
\text { [41] }\end{array}$ & $\begin{array}{l}\text { Students from } \\
\text { Entrepreneurship } \\
\text { Subject program, STKIP } \\
\text { PGRI Nganjuk (151) }\end{array}$ & $\begin{array}{l}\text { Quantitative } \\
\text { descriptive } \\
\text { correlational type }\end{array}$ & $\begin{array}{l}\text { The blended learning model has a positive effect } \\
\text { on improving technopreneurship skills }\end{array}$ \\
\hline $\begin{array}{l}\text { Paper } 10 \\
\text { [42] }\end{array}$ & $\begin{array}{l}\text { The students from } \\
\text { Biology Education } \\
\text { Study Program at } \\
\text { Universitas } \\
\text { Muhammadiyah } \\
\text { Surakarta (17) }\end{array}$ & $\begin{array}{l}\text { Pre-experimental } \\
\text { design using One } \\
\text { Shot Case Study }\end{array}$ & $\begin{array}{l}\text { Peer learning has a positive impact on improving } \\
\text { the average grade acquisition on student } \\
\text { performance in preparing a class action research } \\
\text { proposal and cognitive skills }\end{array}$ \\
\hline
\end{tabular}

According to Table 3, these findings show that blended learning and peer tutor have many positive impacts on learning processes in higher education. The impact can simultaneous in increasing student outcome such as creative thinking, network learning, math and science, cognitive skill.

Blended learning with peer tutor effectived in improving students thinking skill. According to Table 3 , there were two articles showed that this model give positive impact on creative thinking skill and critical thinking skill. There were five articles shows that this model can improve student cognitive skill such as in math. Others showed that this model gave positive impact on students soft skill, two articles showed in technopreneurship skills and one paper showed that this model can improve quality of lecture.

In this section, we will answer the research question about How Students' Outcomes can be increased by Blended learning and peer tutor. Blended learning implementations in higher education, showing the educational technology skill as a transversal and alternative concept [43]. It has 10 categories of critical factors such as technology, didactics, course outcome, collaboration, and social presence, course design, synchronicity and asynchronicity, the heritage from technologyenhanced distance courses, Multimodal overloading, Trends and hypes, and economy [44]. Blended learning will be effective if several activities such as face-to-face, online and independent learning are properly combined so as to improve student learning outcomes and skills [45].

To take full advantage of the opportunities that blended learning, there is some process that must be considered making well-informed, commitment with this way of teaching, pilot testing, where blended Learning requires creating appropriate ecologies for faculty to (re)design and offer courses that get the best from face-to-face and virtual learning environments, initiatives that transform educational practices with the support of technology [46]. To guide higher education when they use blended learning, a framework has been developed such as 
institutional considerations to address support needs (the what); an overview of change agents driving the move towards enhanced blended learning (the why), processes that facilitate enhanced blended learning (the how) and stakeholder groups that should be involved in the transition (the who) [47].

Peer teaching gives benefit for the generic skills development and metacognitive training and lectures need to stimulate students' metacognitive skills and lifelong learning in knowledge society through peerteaching [48]. There are some factors in controlling the successful Peer Teaching Method in Higher Education gender, GPA, and age [49]. Female students have been proved to prefer this method to male students. If the GPA is high, the satisfaction of peer teaching will be higher. In contrast, if the age of the students is higher, the satisfaction of peer teaching will be lower.

\section{CONCLUSION}

As a conclusion, the result of the existing study had shown that blended learning and peer tutor was a suitable learning model in improving students' outcomes at Higher Education in Pandemic Era. Blended learning and peer tutor success to increase students outcome which was satisfaction and confidence. Results showed that Indonesia Student that used blended learning and peer tutor was more confident and show higher achievement in learning. The recommendation for the next study is to develop a new model integrated between Blended Learning and Peer tutor.

\section{AUTHORS' CONTRIBUTIONS}

Nurfina Aznam, Jumadi Jumadi, and Heru Nurcahyo contributed to the design and implementation of the research.

Yusman Wiyatmo and Riki Perdana contributed to the analysis of the results and to the writing of the manuscript.

\section{ACKNOWLEDGMENTS}

This study supported and funded by LPPM Universitas Negeri Yogyakarta.

\section{REFERENCES}

[1] Nurkholis, Dampak Pandemi Novel-Corona Virus Disiase (Covid-19) terhadap Psikologi dan Pendidikan serta Kebijakan Pemerintah, Jurnal PGSD 6(1) (2020) 39-49. DOI: https://doi.org/10.32534/jps.v6i1.1035
[2] A. Purwanto, R. Pramono, M. Asbari et al., Studi Eksploratif Dampak Pandemi Covid-19 terhadap Proses Pembelajaran Online di Sekolah Dasar, EduPsyCouns Journal Education, Psychology and Counseling 2(1) (2020) 1-12.

[3] N.P. Lestari, Menimbang Mahalnya Biaya Lockdown, Arsip Publikasi Ilmiah Biro Administrasi Akademik, 2020. Accessed on: Aug. 20, 2020. [Online]. Available: http://research-

report.umm.ac.id/index.php/APIBAA/article/vie w/3459

[4] A. Habibi, Normal Baru Pasca Covid-19, ADALAH Buletin Hukum \& Keadilan 4(1) (2020) 1-8.

[5] J. Bowyer, Evaluating Blended Learning: Bringing The Elements Together, Research Matters A Cambridge Assessment, 2017. Accessed on: Aug. 27, 2020. [Online]. Available:

http://www.cambridgeassessment.org.uk/researc h- matters /

[6] P. Vanichvasin, Development of The SocialMedia-Based Blended Learning Course to Enhance Student Learning: A Case Study on A Social Science Course, Asian Social Science 14(9) (2018) 58-69. DOI: https://doi.org/10.5539/ass.v14n9p58

[7] D. Akgündüz, O. Akinoglu, The Impact of Blended Learning and Social Media-Supported Learning on The Academic Success and Motivation of The Students in Science Education, Egit. ve Bilim, 42(191) 2017 69-90. DOI: https://doi.org/10.15390/EB.2017.6444

[8] D. Akgunduz, O. Akinoglu, The Effect of Blended Learning and Social Media-Supported Learning on The Students' Attitude and SelfDirected Learning Skills in Science Education, Turkish Online Journal Education Technology 15(2) (2016) 106-115.

[9] J. Hofman, Blended Learning in What Works in Talent Development, Association for Talent Development, 2018.

[10]R. Boelens, M. Voet, B. De Wever, The Design of Blended Learning in Response to Student Diversity in Higher Education: Instructors' Views and Use of Differentiated Instruction in Blended Learning, Computers \& Education 120 (2018) 197-212. DOI: https://doi.org/10.1016/j.compedu.2018.02.009

[11]A. Kristanto, M. Mustaji, A. Mariono, The Development of Instructional Materials E- 
Learning Based on Blended Learning," International Education Studies 10(7) (2017) 1017. DOI: https://doi.org/10.5539/ies.v10n7p10

[12]K.F. Hew, W.S. Cheung, Using Blended Learning: Evidenc Based Practices, Springer, 2015. DOI: https://doi.org/10.1007/978-981-287$\underline{089-6}$

[13] J. Broadbent, Comparing Online and Blended Learner's Self-Regulated Learning Strategies and Academic Performance, The Internet Higher Education $33 \quad$ (2017) 24-32. DOI:. https://doi.org/10.1016/j.iheduc.2017.01.004

[14]A.A. Alfalih, A.A. Alfalih, The Impact of Background Characteristics on Graduate School Attendance: Evidence from A Developing Economy, Journal of The Knowledge Economy (2020) 1-21. DOI: https://doi.org/10.1007/s13132-020-00636-2

[15] S. Imai, A.A. Ravankar, M. Shimamura, T.E. Takasuka, G. Chiba, Y. Yamanaka, Discussion on a method of team-based-learning style lecture for graduate students in a research university, in: Proceedings - 2016 5th IIAI International Congress on Advanced Applied Informatics, IEEE, Piscataway, New Jersey, 2016.

[16] M.S. Tong, D. Wang, G.C. Wan, Analysis and reform of engineering curriculums for graduate students in China, in: Proceedings of 2017 IEEE International Conference on Teaching, Assessment and Learning for Engineering (TALE), IEEE, Piscataway, New Jersey, 2017.

[17] T.-H. YANG, K.-Q. QIN, T.-H. JIANG, Practical teaching exploration based on the cultivation of graduate students' innovative and practice ability, in: $5^{\text {th }}$ International Conference on Education and Social Development (ICESD), DEStech, Pennsylvania, 2020.

[18] J.O. Wao, R. Ries, I. Flood, S. Lavy, M.E. Ozbek, Relationship Between Admission Gre Scores and Graduation GPA Scores of Construction Management Graduate Students, International Journal of Construction Education and Research 12(1) (2016) 12-21. DOI: https://doi.org/10.1080/15578771.2015.105056

[19] T. Holland, Impact of A Departmental Instructional Skills Course on Graduate Students' Beliefs about Science Teaching and Learning, Journal of College Science Teaching 47(6) (2018) 57-65.

[20] B. Leibowitz, V. Bozalek, P. Kahn, Theorising Learning to Teach in Higher Education ( $\left.1^{\text {st }} \mathrm{Eds}\right)$, Routledge, 2016.
[21] Ghalley et al., The Effects of Peer Tutoring on Seventh-Grade Students' Learning in Science, Asian Journal Education Social Studies 4(3) (2019) 1-12. DOI: https://doi.org/10.9734/ajess/2019/v4i330121

[22] A.F. Made, A. Hasan, S. Burgess, D. Tuttle, N. Soetaert, The Effect of Peer Tutoring in Reducing Achievement Gaps: A Success Story, Journal of Computing Sciences in Colleges 7 (2019).

[23] S.L. Gan, K.S. Hong, The Effectiveness of Peer Tutoring in The Teaching of Mathematics," Malaysian Journal Learning and Instruction 7 (2010) 1-20. DOI: https://doi.org/10.32890/mjli.7.2010.7622

[24] N. Sansone, M.B. Ligorio, S.L. Buglass, Peer ETutoring: Effects on Students' Participation and Interaction Style in Online Courses, Innovations in Education and Teaching International 55(1) (2018) 13-22. DOI: https://doi.org/10.1080/14703297.2016.1190296

[25] C. Klopper, S. Drew, Teaching for Learning and Learning for Teaching, Professional Learning, SensePublisher, Rotterdam, 2015, pp. 1-11. DOI: https://doi.org/10.1007/978-94-6300-289-9_1

[26] R.R. Agne, H.L. Muller, Discourse Strategies That Co-Construct Relational Identities in STEM Peer Tutoring, Communication Education 68(3) (2019) 265-286. DOI: https://doi.org/10.1080/03634523.2019.1606433

[27] L.R. Ghalley, S. Tobgay, B.M. Rai, D. Penjor, G. Oli, S. Tenlo, The Effects of Peer Tutoring on Seventh-Grade Students' Learning in Science, Asian Journal of Education and Social Studies 4(3) (2019) 1-12. DOI: https://doi.org/10.9734/ajess/2019/v4i330121

[28] S.O. Olajide, Effects of Field Trip and Peer Tutoring Instructional Strategies on Students' Science Process Skills Acquistion in Basic Science and Technology in Junior Secondary Schools in Osun State, Journal of Education, Society and Behavioural Science 32(4) (2019) 112.

DOI: https://doi.org/10.9734/jesbs/2019/v32i430186

[29] S.L. Gan, K.S. Hong, The Effectiveness of Peer Tutoring in The Teaching of Mathematics, Malaysian Journal Learning and Instruction 7 (2019) 113-132. DOI: https://doi.org/ $\underline{0.32890 / \mathrm{mjli} .7 .2010 .7622}$

[30] L. De Backer, H. Van Keer, M. Valcke, Eliciting Reciprocal Peer-Tutoring Groups' Metacognitive Regulation through Structuring and 
Problematizing Scaffolds, The Journal of Experimental Education 84(4) (2016) 804-828. DOI:

https://doi.org/10.1080/00220973.2015.1134419

[31] D. Moher, A. Liberati, J. Tetzlaff, DG. Altman, The PRISMA Group, Preferred Reporting Items for Systematic Reviews and Meta-Analyses: The PRISMA Statement. PLoS Medicine 6(7) (2009). DOI:

https://doi.org/10.1371/journal.pmed.1000097

[32] N.F.S.M. Saadon, I. Ahmad, A.N.C. Pee, The implementation of augmented reality in increasing student motivation: systematic literature review, in: IOP Conference Series: Materials Science and Engineering, vol. 854, IOP Publising, Bristol, 2020. DOI: https://doi.org/10.1088/1757899X/854/1/012043

[33] Yustina, W. Syafii, R. Vebrianto, The Effects of Blended Learning and Project-Based Learning on Pre-Service Biology Teachers' Creative Thinking Skills through Online Learning in The COVID-19 Pandemic, Journal Pendidikan IPA Indonesia 9(3) (2020) 408-420. DOI: https://doi.org/10.15294/jpii.v9i3.24706

[34]R. Rachmadtullah, Use of Blended Learning with Moodle: Study Effectiveness in Elementary School Teacher Education Students during The COVID-19 Pandemic, International Journal Advanced Science Technology 29(7) (2020) 3272-3277.

[35] A. Fadillah, D. Nopitasari, B.P. Pradja, Blended Learning Model during The Covid-19 Pandemic: Analysis of Student's' Mathematical Disposition, JTAM (Jurnal Teori dan Aplikasi Matematika 4(2) (2020) 173-181. DOI: https://doi.org/10.31764/jtam.v4i2.2582

[36] G.A. Rahmanda, I.K. Sandhi, K. Sunaryo, Analysis of the effect of blended learning implementation to academic productivity performance in beginning pandemic, in: Proceeding of LPPM UPN "Veteran" Yogyakarta Conference Series 2020-Economic and Business Series, LPPM UPN "Veteran" Yogyakarta, vol 1, RSF PRESS \& Research Synergy Foundation, Yogyakarta, 2020, pp. 141146. DOI: https://doi.org/10.31098/ebs.v1i1.60

[37] Idawati, A. Wicaksono, Khaerrunnisa, Development of blended learning based moodle in fiction appreciation at indonesian language and literature education study program, in: Advances in Social Science, Education and Humanities Research, Proceedings of The $5^{\text {th }}$ Progressive and Fun Education International
Conference (PFEIC), Atlantis Press, Paris, 2020. DOI: https://doi.org/10.2991/assehr.k.201015.011

[38]H. Hasanah, M.N. Malik, Blended Learning in Improving Students' Critical Thinking and Communication Skills at University, Cypriot Journal of Education Sciences 15(5) (2020) 1295-1306.

DOI: https://doi.org/10.18844/cjes.v15i5.5168

[39] K. Suryati, I.G. Adnyana, Blended Learning Strategies of Telegram-Assisted Learning Towards Student Mathematics Learning Results Reviewed from Learning Style, JTAM (Jurnal Teori dan Aplikasi Matematika 4(2) (2020) 133144.

DOI:

https://doi.org/10.31764/jtam.v4i2.2438

[40] D.D. Prasetya, A. Pinandito, Y. Hayashi, T. Hirashima, The performance of extended scratch-build concept mapping tool in blended learning, in: 2020 4th International Conference on Vocational Education and Training (ICOVET), IEEE, Piscataway, New Jersey, 2020, pp. 345-349. https://doi.org/10.1109/ICOVET50258.2020.923 $\underline{0047}$

[41] V.S.A. Hariyono, Contribution of Project-Based Blended Learning (PJB2L) Learning Model to Technoprenuership Ability in Higher Education, International Journal Advanced Multidisciplinary Scientific Research 3(4) (2020) 1-15. DOI: https://doi.org/10.31426/ijamsr.2020.3.4.3211

[42] Y. Gayatri, Peer and self assessment in elearning using moodle and whatsapp as scaffolding to improve students' ability tobe selflearners, in: Proceeding International Webinar in Education, Universitas Muhamadiyah Surabaya, Surabaya, 2020, pp. 82-87.

[43]R. Castro, Blended Learning in Higher Education: Trends and Capabilities, Education and Information Technologues 24(4) (2019) 2523-2546. DOI: https://doi.org/10.1007/s10639019-09886-3

[44] P. Mozelius, E. Hettiarachchi, Critical Factors for Implementing Blended Learning in Higher Education, International Journal of Information and Communication Technologies in Education 6(2) (2017) 37-51. DOI: https://doi.org/10.1515/ijicte-2017-0010

[45]D.R. Serrano, M.A. Dea-Ayuela, E. GonzalezBurgos, A. Serrano-Gil, A. Lalatsa, Technologyenhanced Learning in Higher Education: How to Enhance Student Engagement through Blended Learning, European Journal of Education 54(2) 
(2019) 273-286.

https://doi.org/10.1111/ejed.12330

[46]Á.H. Galvis, Supporting Decision-Making Processes on Blended Learning in Higher Education: Literature and Good Practices Review, International Journal of Educational Technology in Higher Education 15(1) (2018) 138. DOI: https://doi.org/ 10.1186/s41239-0180106-1

[47] J. Adekola, V.H.M. Dale, K. Gardiner, Development of An Institutional Framework to Guide Transitions into Enhanced Blended
Learning in Higher Education, Research in Learning Technology 25 (2017). DOI: https://doi.org/10.25304/rlt.v25.1973

[48] M. Stigmar, Peer-to-Peer Teaching in Higher Education: A Critical Literature Review, Mentoring \& Tutoring: Partnership in Learning 24(2) (2016) 124-136. DOI: https://doi.org/10.1080/13611267.2016.1178963

[49] J. Samarkjarn, N. Irawan, Factors in Controlling The Successful Peer Teaching Method in Higher Education, Education 5(1) (2020) 1-7. DOI: https://doi.org/ 10.32528/ellite.v5i1.3126 